\title{
EKSISTENSI PEDAGANG KAKI LIMA(PKL) DI JALAN ARTERI PRIMER, KOTA SINGARAJA
}

\author{
Amirul Ikram ${ }^{\bowtie}$, I Made Sarmita, I Putu Ananda Citra \\ Lembaga Penelitian dan Pengabdian kepada Masyarakat, Universitas Semarang, Indonesia \\ DOI: $\underline{\text { http://dx.doi.org/10.26623/ jdsb.v21i2.1698 }}$
}

\begin{abstract}
Abstrak
Penelitian ini bertujuan untuk mengetahui faktor yang melatarbelakangi eksisnya Pedagang Kaki Lima (PKL) di jalan Arteri Primer Kota Singaja, Bali, dengan fokus penelitian pada karakteristik, motivasi dan strategi PKL. Pada lokasi tersebut banyak terdapat PKL yang menjalankan usahanya pada malam hingga dini hari. Penelitian sebelumnya di Kota Singaraja fokus pada PKL yang menjalankan usaha pada pagi hingga sore hari, namun lokasi yang dikaji kurang pada jalan utama kota, seperti Jalan Arteri Primer yang merupakan jalan yang berdaya guna tinggi. Sehingga menarik untuk dilakukan kajian pada lokasi dan waktu tersebut. Penelitian ini menggunakan metode deskriptif dan analisis kualitatif dengan sampel sebanyak 43 orang yang ditentukan sesuai kriteria penelitian. Pengumpulan data menggunakan metode observasi dan wawancara mendalam. Hasil penelitian menunjukkan bahwa karakteristik PKL di Jalan Arteri Primer, Kota Singaraja didominasi oleh orang yang tingkat pendidikannya pada jenjang SMP, lama berjualan selama $3-4$ jam permalam, dengan penghasilan rata-rata kurang dari 500 ribu permalam. Motivasi menentukan lokasi bagi PKL dengan mencari tempat strategis, kecil bahkan tidak adanya biaya pangkal serta mudah untuk dijangkau. Strategi yang sering digunakan oleh PKL berupa public relation atau membangun hubungan dengan konsumen dan mempertahankan keberadaannya, sehingga tetap eksisnya usaha yang mereka lakukan. Penelitian ini akan menambah khazanah ilmu penetahuan terhadap kajian Geografi Ekonomi.
\end{abstract}

\section{Abstract}

This study aims at investigating the factors behind the existence of street vendors at Arteri Primer Street, Singaraja, Bali. This study focuses on the characteristics, motivation, and strategy of street vendors. At that location, there are many street vendors who run their business at night until early morning. The previous research focuses on the street vendors who run their business in the morning until the evening. However, the setting of the previous study did not on the main street, such as Primary Arterial Street which is a highly efficient road. Concerning this matter, the researcher intended to conduct study at that location and that time. This study uses descriptive qualitative method. There are 43 people involved as sample in this research which are selected based on categories. The data are collected through observation and depth interview. The result of the study showed that the characteristics of street vendors at Arteri Primer Street, Singaraja are dominated by people whose education level is at the junior high school level, working for 3-4 hours per night, with an average income of less than 500 thousand per night. Further, street vendors' motivations in order to determine the location are strategic place, small, without fees, 
Dinamika Sosial Budaya, Vol 22, No. 2, Desember 2020, pp 294-305

p-ISSN: 1410-9859\& e-ISSN: 2580-8524

http://journals.usm.ac.id/index.php/idsb

and easy to reach. Moreover, the strategies used by street vendors are in the form of public relations or building relationships with consumers and maintaining their existence, therefore, they can keep their businesses existence. This research are expected to be able to enrich the knowledge about Economic Geography.

Keywords: Eksistence; Arteri Primer Street; Street Vendors 


\section{PENDAHULUAN}

Pedagang kaki lima (PKL) merupakan salah satu bagian dari sektor informal, yang berdasarkan status kerjanya termasuk dalam pekerja yang berusaha sendiri, berusaha sendiri dengan bantuan keluarga atau anggota keluarga dengan tidak dibayar (Nazara, 2010) dalam International Labour Organization (ILO). Menurut Widyaningrum (2009), PKL merupakan unit usaha informal yang dilakukan di pinggir jalan, dan merupakan perpanjangan dari usaha formal.

Fenomena informal PKL ini dapat dijumpai di berbagai daerah di Indonesia, diantaranya Provinsi Bali. Bali yang menjadi ikon pariwisata nasional di Indonesia, menjadikan daerah ini tidak hanya dikunjungi oleh para wisatawan untuk berlibur, namun juga menjadi salah satu tempat pengaduan nasib dalam dunia usaha bagi sebagian pendatang. Hal ini juga dapat dibuktikan dalam artikel Trendyari dan Yasa (2014), didapati sebesar 79\% pendatang ke Kota Denpasar-Bali untuk mencari lapangan usaha, terutama pada usaha/jasa kemasyarakatan, sosial, dan perorangan dalam hal ini PKL menjadi salah satunya.

Kota Singaraja yang terletak di Kabupaten Buleleng, Provinsi Bali, sering disebut sebagai kota pendidikan memiliki faktor tersendiri dalam menarik pendatang. Diantaranya keberadaan salah satu kampus negeri yang ada di Bali yaitu Universitas Pendidikan Ganesha (Undiksha), membuat wilayah ini tidak akan lepas dari kegiatan sektor informal-PKL. Penelitian yang dilakukan oleh Rahayuni (2015) terhadap pola PKL yang ada di Kota Singaraja menyatakan, beberapa kawasan yang menjadikan lokasi penyebaran PKL yang ada di Kota Singaraja, diantaranya kawasan perumahan, pusat pendidikan, pusat rekreasi dan pertokoan/pasar.
Rahayuni (2015), mengatakan bahwa aktivitas PKL berkembang dengan mengikuti jalan penghubung atau yang menghubungkan jalan utama. Pola penyebaran PKL di Kota Singaraja yang dilakukan pada waktu pagi hingga sore hari tersebut dipengaruhi oleh lokasi yang terbilang strategis, dengan menempati kawasan perumahan, pusat pendidikan, pusat rekreasi dan pertokoan/pasar. Penentuan lokasi dalam menjalankan aktivitasnya mempertimbangkan adanya kegiatan atau aktivitas bersama pada waktu yang sama di sepanjang hari. Dampak yang ditimbulkan akibat keberadaan PKL berupa adanya kemacetan dan kesemrautan. Banyaknya sampah akibat aktivitas PKL yang tidak mengelola sampah dengan baik.

Pada malam hingga dini hari, PKL di Kota Singaraja tersebar tidak merata. Jika kita ulas dari penelitian sebelumnya, yang kurang mengidentifikasi masalah PKL yang berlokasi di jalan utama kota, terutama Jalan Arteri Primer yang merupakan jalan dengan kapasitas berdaya guna tinggi, yang menghubungkan antara pusat kegiatan kota dengan pusat kegiatan kota lainnya (PPRI, tentang Jalan), maka akan kurang rasanya. Jalan Gajah Mada, Jalan Ngurah Rai, Jalan A. Yani, Jalan Diponogoro dan Jalan Surapati yang tergolong dalam jenis Jalan Arteri Primer yang ada di Kota Singaraja akan sangat menarik kiranya untuk dikaji mengenai keberadaan PKL.

Di Jalan Arteri Primer Kota Singaraja, PKL yang berjualan pada malam hingga dini hari cukup unik keberadaannya. Walaupun sama-sama adanya aktivitas PKL, namun di masing-masing lokasi tersebut berbeda dari segi ramainya aktivitas PKL. Jika diperhatikan munculnya aktivitas PKL malam hingga dini hari lebih banyak atau lebih besar pada Jalan A. Yani. Kemunculan PKL malam hingga dini hari, terutama di Jalan A. Yani tersebut menjadi sesuatu yang 
menarik untuk dikaji lebih jauh, dikarenakan pada lokasi tersebut aktivitas PKL siang hari sangat minim, sedangkan pada malam hingga dini hari memiliki aktivitas PKL yang cukup ramai.

Dari hal tersebut menarik kiranya untuk mengkaji fenomena PKL yang berjualan pada malam hingga dini hari lebih jauh. Dikarenakan penelitian sebelumnya kurang atau jarang yang membahas aktivitas PKL malam hingga dini hari. Rumusan masalah yang diangkat mempertanyakan bagimana karakteristik PKL, motivasi PKL, serta strategi yang digunakan oleh PKL dalam menarik minat pembelinya, sehingga dapat diketahui pengaruhnya terhadap eksistensi PKL di Jalan Arteri Primer, Kota Singaraja.

\section{METODE}

Penelitian ini merupakan penelitian deskriptif, yaitu dengan menggambarkan proses atau pola berdasarkan gejala, peristiwa, atau suatu kejadian yang terjadi berdasarkan fenomena kegiatan usaha yang terjadi, terutama pada proses jual beli yang ada di Kota Singaraja, tepatnya di Jalan Arteri Primer, Kota Singaraja, dengan analisis yang digunakan adalah analisis kualitatif, yaitu analisis yang dilakukan terhadap semua pernyataan pedagang sebagai subjek penelitian yang dipaparkan dalam bentuk narasi.

Penelitian ini berlokasi di jalan Arteri Primer, Kota Singaraja, Kabupaten Buleleng, Provinsi Bali, tepatnya pada Jalan Gajah Mada, Jalan Ngurah Rai, Jalan A. Yani, Jalan Diponogoro dan Jalan Surapati, sebagai jalan yang dengan kapasitas berdaya guna tinggi. Sumber data sebanyak 43 PKL yang merupakan data dari seluruh populasi yang ada. Hal ini dikarenakan sifat data terbilang homogen, dengan kriteria berupa PKL yang melakukan usaha di trotoar dan/atau bahu jalan, berjualan pada malam hingga dini hari, yaitu minimal dari jam 19.00 sampai maksimal hingga jam 03.00 Wita, menggunakan sarana meja dan/atau rombong, dan setiap berdagang berada di titik lokasi yang sama.

Data yang dibutuhkan dalam penelitian ini berupa karakteristik PKL, motivasi PKL dan strategi yang digunakan oleh PKL dalam menarik minat pembeli/konsumen. Teknik pengumpulan data berupa observasi dan wawancara mendalam (in depth interview), dengan instrumen yaitu lembar observasi dan pedoman wawancara. Observasi merupakan metode pengumpulan data dengan cara melakukan pencatatan kondisi lapangan secara langsung yang dilakukan secara sistematis, sedangkan wawancara merupakan metode pengumpulan data dengan cara tanya jawab yang dikerjakan dengan sistematis dan berlandaskan tujuan penelitian (Idrus, 2009).

\section{HASIL DAN PEMBAHASAN}

\section{Karakteristik Pedagang Kaki Lima (PKL)} di Jalan Arteri Primer, Kota Singaraja

Data tentang karakteristik PKL di Jalan Arteri Primer, Kota Singaraja dalam penelitian ini dianalisis secara deskriptif kualitatif. Karakteristik PKL dalam penelitian ini, dilihat dari indikator sosial, ekonomi, dan demografi. Terdapat 9 pertanyaan terkait dengan karakteristik PKL ini, diuraian data-data perolehan yang didapat mengenai karakteristik PKL di Jalan Arteri Primer, Kota Singaraja dapat dilihat pada Tabel 1. 
Dinamika Sosial Budaya, Vol 22, No. 2, Desember 2020, pp 294-305

p-ISSN: 1410-9859\& e-ISSN: 2580-8524

http://journals.usm.ac.id/index.php/idsb

Tabel 1 Karakteristik PKL di Jalan

Arteri Primer

$3 \mathrm{Jam}$

3

4 Jam

4

Waktu

$5 \mathrm{Jam}$

berjualan

$6 \mathrm{Jam}$

$7 \mathrm{Jam}$

$8 \mathrm{Jam}$

Modal/mala $\quad<500$ Ribu $\quad 6$

m $>500$ Ribu 1

Pendapatan/ $\quad<500$ Ribu 7

malam

$>500$ Ribu

$20-30$ Tahun 1

30 -40 Tahun -

\begin{tabular}{|c|c|c|c|c|c|c|c|c|c|c|c|}
\hline \multirow{2}{*}{\multicolumn{4}{|c|}{ 281 }} & \multirow{2}{*}{\multicolumn{5}{|c|}{ Jumlah Umur }} & \multirow{2}{*}{\multicolumn{2}{|c|}{$-40-50$ Pegkun }} & \multirow[b]{3}{*}{$\begin{array}{l}6 \\
- \\
\end{array}$} \\
\hline & \multirow{3}{*}{$\begin{array}{l}\text { Indikato } \\
\mathbf{r}\end{array}$} & \multirow{3}{*}{ Aspek } & \multirow{3}{*}{ Satuan Ukur } & & & & & & & & \\
\hline \multirow[t]{2}{*}{ No } & & & & \multirow{2}{*}{$\begin{array}{l}\text { Gaja } \\
\text { h } \\
\text { Mad } \\
\text { a } \\
\end{array}$} & \multirow{2}{*}{$\begin{array}{l}\text { Ngu } \\
\text { Dahogr } \\
\text { fRai }\end{array}$} & \multicolumn{2}{|c|}{$\begin{array}{cc}\text { A. } & \text { Dipo } \\
\text { aYan } & \text { nogo }\end{array}$} & $\begin{array}{l}\text { Su } \\
\text { ra }\end{array}$ & \multicolumn{2}{|c|}{$\begin{array}{l}40-50 \text { Heatsun } \\
\text { Tot en } \\
550 \text { Tahun } \\
\text { aase }\end{array}$} & \\
\hline & & & & & & i St & tattis & $\begin{array}{l}\mathbf{p a} \\
\mathbf{t i}\end{array}$ & Sudal & $(\%)$ & 6 \\
\hline (1) & (2) & (3) & (4) & (5) & (6) & (7) $)^{\mathrm{Pe}}$ & erkzy) & (19) & B(de) & (11) & 1 \\
\hline \multirow{4}{*}{1} & \multirow{4}{*}{ Sosial } & \multirow{4}{*}{ Pendidikan } & SD & 1 & - & $8 \mathrm{St}$ & tatūus & 2 & $\mathrm{MHgr}$ & $\begin{array}{l}25,5 \\
n 8\end{array}$ & 3 \\
\hline & & & SMP & 4 & 3 & $4 \begin{array}{ll}\mathrm{ke} \\
\mathrm{n}\end{array}$ & ependudt & $\begin{array}{l}\mathrm{aka} \\
4\end{array}$ & PEPd & $\begin{array}{l}41,8 \\
d_{y^{k}} \text { asli }\end{array}$ & 4 \\
\hline & & & SMA & 2 & 2 & 3 & 4 & 2 & 13 & $\begin{array}{l}30,2 \\
3\end{array}$ & \\
\hline & & & $\begin{array}{l}\text { Perguruan } \\
\text { Tinggi }\end{array}$ & - & - & 1 & - & - & 1 & 2,33 & \\
\hline \multirow{4}{*}{2} & \multirow{4}{*}{ Ekonomi } & \multirow{2}{*}{ Tipe Usaha } & Keluarga & 6 & 5 & 15 & 7 & 8 & 41 & $\begin{array}{l}95,3 \\
5\end{array}$ & \\
\hline & & & Non keluarga & 1 & - & 1 & - & - & 2 & 4,65 & \\
\hline & & \multirow{2}{*}{$\begin{array}{l}\text { Pengalaman } \\
\text { berdagang }\end{array}$} & $<10$ Tahun & 2 & 4 & 7 & 7 & 8 & 28 & $\begin{array}{l}65,1 \\
2\end{array}$ & \\
\hline & & & $>10$ Tahun & 5 & 1 & 9 & - & - & 15 & $\begin{array}{l}34,8 \\
8\end{array}$ & \\
\hline
\end{tabular}


Tabel 1 menunjukkan karakteristik sosial pada PKL yang melakukan usaha malam hingga dini hari di 5 titik Jalan Arteri Primer pada dasarnya sama dan berbanding lurus dengan yang dikatakan oleh Widjajanti (2012) serta Winoto dan Budiani (2017). Pada indikator sosial terdapat kesamaan dengan yang dikatakan oleh peneliti sebelumnya, yaitu tidak berpengaruhnya tingkat pendidikan terhadap keberhasilan usaha ini, hal ini dikarenakan usaha yang dijalankan tidak memerlukan keahlian khusus yang hanya dapat diperoleh melalui jenjang pendidikan. PKL di Jalan Arteri Primer Kota Singaraja di dominasi oleh orang yang tingkat pendidikannya pada jenjang SMP, yaitu dengan persentase $41,86 \%$. Hal selaras dengan yang ditemui oleh Duwit, Kumurur dan Moniaga (2015). Namun sedikit berbeda dengan yang ditemui oleh Harahap (2016) dengan hasil temuan PKL lebih didominasi oleh orang yang berpendidikan pada jenjang SMA.

Penelitian sebelumnya pada karakteristik ekonomi PKL juga hampir sama dengan karakteristik yang ditemukan pada PKL di Jalan Arteri Primer Kota Singaraja. Usaha PKL yang dijalankan di kelima ruas jalan rata-rata merupakan usaha milik sendiri yang bertujuan untuk pemenuhan ekonomi keluarga. Pengalaman sebagai PKL sudah menjalaninya dari 1 sampai 20 tahun terutama pada Jalan A. Yani yang cukup banyak PKL, dengan pengalaman lebih dari 10 tahun berjualan, dengan rata-rata waktu berjualan permalam 3 sampai 4 jam, yang disesuaikan dengan waktu karena malam hari dan cepat atau tidaknya dagangan terjual. Hal tersebut berbanding lurus dengan Handayani (2013) serta Winoto dan Budiani (2017). Namun pada waktu berjualan sedikit lebih pendek dikarenakan usaha yang dilakukan pada waktu malam hari. Modal dan pendapatan pada penelitian ini terhitung permalam.
Rata-rata modal serta pendapatan yang digunakan oleh PKL permalam kurang dari 500 ribu, jika dihitung perbulan rata-rata pendapatan perbulan yaitu 4 hingga 9 juta. Pada kasus ini modal dan pendapatan berbanding lurus dengan Duwit, Kumurur dan Moniaga (2015), dan sedikit berbeda dengan penelitian sebelumnya, seperti yang dipaparkan Handayani (2013) berkisar 3 sampai 5 juta perbualan, Winoto dan Budiani (2017) berkisar 2 sampai 5 juta perbulan, serta Harahap (2016) berkisar 2 hingga 6 juta perbulan.

Pada indikator demografi, PKL yang rata-rata berusia 30 hingga 50 tahun dengan status perkawinan lebih banyak yang sudah menikah atau berkeluarga. Sama dengan yang dipaparkan oleh Handayani (2013), Winoto dan Budiani (2017), serta Harahap (2016). Pada status kependudukan, di penelitian ini lebih dominan PKL dengan status kependudukan berupa penduduk asli Kota Singaraja dengan persentase $79,07 \%$, kecuali pada Jalan Nguah Rai yang lebih banyak didominasi oleh migran. Pada kasus status kependudukan ini beberapa penelitian berbanding lurus, seperti Winoto dan Budiani (2017). Pada Handayani (2013) berbanding terbalik dari temuan pada PKL di Jalan Arteri Primer ini.

\section{Motivasi Pedagang Kaki Lima (PKL) di Jalan Arteri Primer, Kota Singaraja}

Pengumpulan data pada variabel ini menggunakan instrumen lembar wawancara dan lembar observasi yang dipadukan. Terdapat 3 indikator yang dikaji yaitu dari segi motivasi sosial, motivasi ekonomi dan motivasi aksesibilitas para PKL, dengan 4 pertanyaan yang ditanyakan, yang dapat dilihat pada Tabel 2. 
Dinamika Sosial Budaya, Vol 22, No. 2, Desember 2020, pp 294-305

p-ISSN: 1410-9859\& e-ISSN: 2580-8524

http://journals.usm.ac.id/index.php/idsb

Tabel 2 Motivasi PKL di Jalan Arteri

Primer

\begin{tabular}{|c|c|c|c|c|c|c|c|c|c|c|}
\hline \multirow[b]{2}{*}{ No } & \multirow[b]{2}{*}{ Indikator } & \multirow[b]{2}{*}{ Aspek } & \multirow[b]{2}{*}{ Satuan ukur } & \multicolumn{5}{|c|}{ Jumlah } & \multirow[b]{2}{*}{$\begin{array}{l}\text { Tot } \\
\text { al }\end{array}$} & \multirow[b]{2}{*}{$\begin{array}{l}\text { Perse } \\
\text { n } \\
\text { tase } \\
(\%)\end{array}$} \\
\hline & & & & $\begin{array}{l}\text { Gaja } \\
\text { h } \\
\text { Mad } \\
\text { a }\end{array}$ & $\begin{array}{l}\text { Ngu } \\
\text { rah } \\
\text { Rai }\end{array}$ & $\begin{array}{l}\text { A. } \\
\text { Yani }\end{array}$ & $\begin{array}{l}\text { Dipo } \\
\text { nogo } \\
\text { ro }\end{array}$ & $\begin{array}{l}\text { Su } \\
\text { ra } \\
\text { pa } \\
\text { ti }\end{array}$ & & \\
\hline (1) & (2) & (3) & (4) & $(5)$ & (6) & (7) & (8) & (9) & (10) & (11) \\
\hline \multirow{7}{*}{1} & \multirow[t]{7}{*}{ Sosial } & \multirow{2}{*}{$\begin{array}{l}\text { Konsume } \\
\mathrm{n}\end{array}$} & Banyak Pembeli & 7 & 3 & 15 & 7 & 8 & 40 & 93,02 \\
\hline & & & $\begin{array}{l}\text { Ada Target Pasar } \\
\text { Tertentu }\end{array}$ & - & 2 & 1 & - & - & 3 & 6,98 \\
\hline & & \multirow[t]{5}{*}{$\begin{array}{l}\text { Pemiliha } \\
\text { n Lokasi }\end{array}$} & $\begin{array}{l}\text { Dekat } \\
\text { Keramaian }\end{array}$ & - & 2 & - & - & 1 & 3 & 6,98 \\
\hline & & & $\begin{array}{l}\text { Dekat Tempat } \\
\text { Tinggal }\end{array}$ & 1 & - & 3 & 7 & 4 & 15 & 34,88 \\
\hline & & & Dirasa Strategis & 5 & 3 & 9 & 1 & 3 & 21 & 48,84 \\
\hline & & & $\begin{array}{l}\text { Meneruskan } \\
\text { Usaha }\end{array}$ & - & - & 2 & - & - & 2 & 4,65 \\
\hline & & & Alasan lainnya & 1 & - & 2 & 1 & - & 4 & 9,30 \\
\hline \multirow{2}{*}{2} & \multirow[t]{2}{*}{ Ekonomi } & \multirow{2}{*}{$\begin{array}{l}\text { Biaya } \\
\text { Pangkal }\end{array}$} & Ada & 1 & 2 & 4 & - & 2 & 9 & 20,93 \\
\hline & & & Tidak Ada & 6 & 3 & 12 & 7 & 6 & 34 & 79,07 \\
\hline \multirow{4}{*}{3} & \multirow[t]{4}{*}{$\begin{array}{l}\text { Akesibilit } \\
\text { as }\end{array}$} & \multirow[t]{4}{*}{$\begin{array}{l}\text { Keterjang } \\
\text { kauan }\end{array}$} & $\begin{array}{l}\text { Mudah } \\
\text { Dijangkau }\end{array}$ & 7 & 5 & 16 & 7 & 8 & 43 & 100 \\
\hline & & & Sulit Dijangkau & - & - & - & - & - & $\mathbf{0}$ & $\mathbf{0}$ \\
\hline & & & $\begin{array}{l}\text { Jarak tempat } \\
\text { tinggal }<1 \mathrm{~km}\end{array}$ & 4 & - & 3 & 7 & 6 & 20 & 46,51 \\
\hline & & & $\begin{array}{l}\text { Jarak tempat } \\
\text { tinggal }>1 \mathrm{~km} \\
\end{array}$ & 3 & 5 & 13 & - & 2 & 40 & 93,02 \\
\hline
\end{tabular}


Pada Tabel 2 menunjukkan motivasi PKL dalam menjalankan usahanya. Pada pemilihan lokasi, lokasi yang dirasa strategis menjadi faktor dominan yang menyebabkan PKL dalam memilih lokasi berjualan, seperti pada Jalan A. Yani dekat Pasar Anyar yang merupakan pusat keramayan Kota Singaraja. Namun pada Jalan Diponogoro dan Jalan Surapati lebih dominan beralasan dekat dengan tempat tinggal sebagai pemilihan lokasi dalam berjualan, dikarenakan pembeli lebih banyak adalah penduduk sekitar lokasi. Kedua hal tersebut juga sama dengan pemaparan oleh Utdwinata dan Murni (2019) serta Sapar, Lumintang dan Susanto (2006) bahwa motivasi sosial PKL dalam pemilihan lokasi dominan pada tempat yang strategis dan dekat dengan tempat tinggal PKL.

Motivasi PKL dalam berjualan dan menentukan lokasi juga dapat dipandang dari segi ekonomi. Utdwinata dan Murni (2019) serta Sapar, Lumintang dan Susanto (2006) memaparkan, bahwa PKL biasa memilih lokasi yang sekiranya minim pada segi ekonomi. Begitu pula pada PKL yang ada di 5 ruas Jalan Arteri Primer, Kota Singaraja, dengan motivasi berjualan di lokasi masingmasing dikarenakan rendahnya biaya pangkal bahkan sampai tidak ada. Biaya pangkal yang rendah hingga tidak ada tersebut dipengaruhi oleh aktivitas PKL yang berjualan pada malam hingga dini hari.

Pada motivasi aksesibilitas PKL semua responden beralasan, lokasi tempat mereka melakukan usaha sangat mudah dijangkau dari tempat tinggal masing-masing PKL. Kesemua hal tersebut berbanding lurus dengan motivasi PKL yang dipaparkan oleh Utdwinata dan Murni (2019) bahwa mudahnya akses ke lokasi penjualan menjadi faktor pemilihan lokasi bagi PKL dalam melakukan usaha. Mudahnya aksesibilitas merupakan faktor terbesar bagi PKL dalam menentukan lokasinya (Sastrawan, Haris, \& Suwena, 2015). Di Jalan Arteri Primer, Kota
Singaraja, akses para PKL menuju lokasi berjualan sangat mudah. Jarak antara rumah PKL ke lokasi mereka berjualan dominan pada jarak lebih dari 1 kilometer, dan hanya pada Jalan Diponogoro yang keseluruhan PKLnya memiliki jarak kurang dari 1 kilometer. 
Dinamika Sosial Budaya, Vol 22, No. 2, Desember 2020, pp 294-305

p-ISSN: 1410-9859\& e-ISSN: 2580-8524

http://journals.usm.ac.id/index.php/jdsb

Strategi Pedagang Kaki Lima (PKL) di

Jalan Arteri Primer, Kota Singaraja

Pada pembahasan strategi PKL ini, ada 2 aspek yang ingin dikaji, yaitu strategi sosial ekonomi yang dilakukan oleh para PKL dalam usahanya menarik minat konsumen. Adapun hasil kajian mengenai strategi PKL di Jalan Arteri Primer, Kota Singaraja dapat dilihat pada Tabel 3.

Tabel 3 Strategi PKL di Jalan Arteri Primer

\begin{tabular}{|c|c|c|c|c|c|c|c|c|c|c|}
\hline \multirow[b]{2}{*}{ No } & \multirow[b]{2}{*}{$\begin{array}{l}\text { Indikato } \\
\mathbf{r}\end{array}$} & \multirow[b]{2}{*}{ Aspek } & \multirow[b]{2}{*}{ Satuan ukur } & \multicolumn{5}{|c|}{ Jumlah } & \multirow[b]{2}{*}{$\begin{array}{l}\text { Tot } \\
\text { al }\end{array}$} & \multirow[b]{2}{*}{$\begin{array}{l}\text { Pers } \\
\text { en } \\
\text { tase } \\
(\%)\end{array}$} \\
\hline & & & & $\begin{array}{l}\text { Gajah } \\
\text { Mada }\end{array}$ & $\begin{array}{l}\text { Ngu } \\
\text { rah } \\
\text { Rai }\end{array}$ & $\begin{array}{l}\text { A. } \\
\text { Ya } \\
\text { ni }\end{array}$ & $\begin{array}{l}\text { Dipo } \\
\text { nogo } \\
\text { ro }\end{array}$ & $\begin{array}{l}\text { Su } \\
\text { ra } \\
\text { pa } \\
\text { ti }\end{array}$ & & \\
\hline (1) & (2) & (3) & (4) & (5) & $(6)$ & $(7)$ & (8) & (9) & (10) & (11) \\
\hline \multirow{7}{*}{1} & \multirow{7}{*}{$\begin{array}{l}\text { Sosial } \\
\text { ekonomi }\end{array}$} & \multirow{2}{*}{$\begin{array}{l}\text { Hubunga } \\
\mathrm{n} \text { Dengan } \\
\text { Konsume } \\
\mathrm{n}\end{array}$} & $\begin{array}{l}\text { Membangun } \\
\text { Hubungan } \\
\text { dengan } \\
\text { konsumen }\end{array}$ & 3 & 4 & 9 & 6 & 5 & 27 & $\begin{array}{l}62,7 \\
9\end{array}$ \\
\hline & & & $\begin{array}{l}\text { Tidak } \\
\text { membangun } \\
\text { hubungan } \\
\text { dengan } \\
\text { konsumen }\end{array}$ & 4 & 1 & 7 & 1 & 3 & 16 & $\begin{array}{l}37,2 \\
1\end{array}$ \\
\hline & & \multirow{5}{*}{$\begin{array}{l}\text { Model } \\
\text { Pemasara } \\
\mathrm{n}\end{array}$} & $\begin{array}{l}\text { Mencari tempat } \\
\text { strategis }\end{array}$ & - & 2 & - & - & 1 & 3 & 6,98 \\
\hline & & & $\begin{array}{l}\text { Mempertahanka } \\
\mathrm{n} \text { keberadaan }\end{array}$ & 7 & 3 & 12 & 4 & 6 & 32 & $\begin{array}{l}74,4 \\
2 \\
\end{array}$ \\
\hline & & & Menghias lapak & - & - & 2 & 1 & - & 3 & 6,98 \\
\hline & & & $\begin{array}{l}\text { Membuat menu } \\
\text { baru }\end{array}$ & - & - & 2 & 2 & 2 & 6 & $\begin{array}{l}13,9 \\
5 \\
\end{array}$ \\
\hline & & & $\begin{array}{l}\text { Menyapa } \\
\text { konsumen untuk } \\
\text { membeli }\end{array}$ & - & 2 & 5 & - & - & 7 & $\begin{array}{l}16,2 \\
8\end{array}$ \\
\hline
\end{tabular}


Seperti yang disebutkan oleh Zulkarnain (2012) sebagai jenis usaha ekonomi menengah, PKL dalam menarik minat pembelinya lebih menggunakan strategi sosial ekonomi. Di Jalan Arteri Primer Kota Singaraja, pada dasarnya strategi yang mereka gunakan juga sebagian besar memiliki kesamaan dengan penelitian terdahulu tentang strategi sosial ekonomi PKL. Sebagai catatan, terdapat PKL yang menggunakan lebih dari satu strategi dalam menarik minat pembelinya.

Membangun hubungan dengan konsumen (public relation) menjadi penerapan strategi yang cukup banyak digunakan oleh para PKL. Strategi ini digunakan karena tidak membutuhkan modal uang dalam penerapannya, sehingga PKL sebagai sektor ekonomi menengah kebawah menggunakannya. Terbukti dari 5 lokasi PKL yang diteliti hanya satu ruas jalan yang PKLnya lebih dominan tidak membangun hubungan, yaitu pada Jalan Gajah Mada dengan 4 dari 7 PKL yang tidak membangun hubungan dengan konsumen. Strategi PKL ini juga ditemui pada Prabowo dan Handoyo (2016), begitu pula pada Rahayu dan Fitanto (2012), yaitu dengan menjalin hubungan baik dengan masyarakat sekitar dan adanya perlakuan khusus pada pelanggan setianya.

Menurut widjajanti (2009) strategi PKL dalam menarik konsumen cenderung memanfaatkan aktivitas-aktivitas sektor formal seperti pusat perbelanjaan dan usaha sektor formal lainnya. Namun hal ini tidak berlaku bagi PKL yang berjualan malam hingga dini hari di Jalan Arteri Primer Kota Singaraja, hanya salah satu pelaku saja yang melakukannya, yaitu PKL pada Jalan Surapati. Strategi dalam menarik konsumen yang dominan terjadi berupa strategi PKL dengan mempertahankan keberadaannya, seperti yang sering dilakukan oleh PKL yang ada di Jalan Gajah Mada dan Jalan A. Yani. Namun hal ini tidak termasuk dalam strategi yang disebutkan oleh Zulkarnain (2012) dan Rahayu dan Fitanto (2012), sehingga dalam hal ini strategi mempertahankan keberadaan oleh para PKL merupakan strategi yang unik dan banyak dilakukan oleh PKL di Jalan Arteri Primer Kota Singaraja.

\section{SIMPULAN}

Berdasarkan hasil penelitian dan pembahasan yang telah diuraikan mengenai karakteristik, motivasi dan strategi yang digunakan oleh PKL yang ada di Arteri Primer, Kota Singaraja, maka dapat disimpulkan sebagai berikut. PKL di Jalan Srteri Primer, Kota Singaraja didominasi oleh orang yang tingkat pendidikannya pada jenjang SMP. Usaha PKL yang dijalankan rata-rata merupakan usaha milik sendiri dengan pengalam berjualan dari $1-20$ tahun. Lama berjualan dominan selama 3 sampai 4 jam permalam, dengan modal dan serta pendapatan kurang dari 500 ribu permalam. PKL yang didominasi oleh orang yang berusia 30 hingga 50 tahun lebih banyak yang sudah berstatus sudah menikah, dan rata-rata merupakan penduduk asli Kota Singaraja. Banyaknya pembeli menjadi faktor dominan yang membuat PKL termotivasi melakukan usaha. Lokasi yang dirasa strategis menjadi pendorong motivasi PKL dalam menentukan posisinya berjualan. Selain itu kecilnya biaya pangkal bahkan tidak ada juga menjadi faktor bagi PKL menentukan lokasi, dengan jarak rumah ke lokasi berjualan para PKL dominan lebih dari 1 kilometer yang mudah di jangkau. Strategi yang sering digunakan berupa public relation yaitu membangun hubungan dengan konsumen. Penggunaan strategi dengan mempertahankan keberadaannya menjadi keunikan tersendiri bagi PKL pada penelitian ini. Terbukti di semua ruas jalan yang diteliti, strategi ini sering menjadi cara yang PKL gunakan 
dalam menarik minat konsumen, sehingga tetap eksisnya usaha yang mereka geluti.

Berdasarkan manfaat penelitian, maka saran yang diajukan berupa, bagi PKL di Kota Singaraja, dalam menarik pelanggan untuk lebih maksimal lagi, diperlukan inovasi-inovasi yang menarik dalam menjajakan barang dagangan yang dijual. Serta penataan tempat berjualan untuk dimaksimalkan. Bagi pemerintah, supaya adanya relokasi untuk tempat bagi para PKL melakukan usahanya agar tidak mengganggu pemandangan kota pada malam hari. Bagi masyarakat Kota Singaraja, supaya tidak hanya berbelanja di toko waralaba saja. Peningkatan ekonomi bagi kalangan ekonomi menengah kebawah dipengaruhi oleh gaya hidup masyarakat dalam mengindahkan usaha yang dilakukan pedagang mikro, kecil dan menengah.

\section{DAFTAR PUSTAKA}

Duwit, B. S., Kumurur, V. A., \& Moniaga, I. L. (2015). PERSEPSI PEDAGANG KAKI LIMA TERHADAP AREA BERJUALAN SEPANJANG JALAN PASAR PINASUNGKULAN KAROMBASAN MANADO. Jurusan Arsitektur, 7(2), 419-427.

Handayani, C. M. S. (2013). Karakteristik Pedagang Kaki Lima (PKL) Di Sentra PKL Surabaya. Majalah Ekonomi, 17(2).

Harahap, E. F. (2016). MODEL KARAKTERISTIK DAN PERANAN PEKERJA INFORMAL DI KOTA PADANG. E-Jurnal Apresiasi Ekonomi, 4(3).

Idrus, M. (2009). Metode Penelitian Ilmu Sosial. Jakarta: Erlangga.

Nazara. (2010). Ekonomi Informal di Indonesia: Ukuran, Komposisi, dan Evolusi. Organisasi Perburuhan Internasional.
Prabowo, U., \& Handoyo, P. (2016). Peran Modal Sosial dalam Mekanisme Survival Pedagang Kaki Lima (PKL) Pentol Bakar di Kawasan Benteng Pancasila (BenPas) Kota Mojokerto. Jurnal Paradigma, 4(1).

Rahayu, Y. S., \& Fitanto, B. (2012). STRATEGI PEDAGANG PASAR TRADISIONAL MENGHADAPI PERSAINGAN dengan RETAIL MODERN dan PREFERENSI KONSUMEN (Studi Kasus Pada Pasar Legi Kota Blitar). Jurnal Ilmiah Mahasiswa FEB, 1(2).

Rahayuni, I. G. A. A., Treman, I. wayan, \& Citra, I. P. A. (2015). Ekonomi Informal di Indonesia: Ukuran, Komposisi, dan Evolusi. Jurnal Pendidikan Geografi Undiksha, 3(2).

Sapar, Lumintang, R. W. E., \& Susanto, D. (2006). FAKTOR-FAKTOR YANG BERKAITAN DENGAN PERILAKU KEWIRAUSAHAAN PEDAGANG KAKILIMA (Kasus Pedagang Kakilima Pemakai gerobak Usaha Makanan Di Kota Bogor). JURNAL P ENYULUHAN, 2(2).

Sastrawan, I. W., Haris, I. A., \& Suwena, K. R. (2015). ANALISIS FAKTORFAKTOR YANG MEMPENGARUHI PEMILIHAN LOKASI USAHA PEDAGANG KAKI LIMA DI PANTAI PENIMBANGAN KECAMATAN BULELENG, KABUPATEN BULELENG. Jurnal Pendidikan Ekonomi Undiksha, 5(1).

Trendyari, A. A. T., \& Yasa, I. N. M. (2014). Analisis Faktor-Faktor Yang Mempengaruhi Migrasi Masuk Ke Kota Denpasar. E-Jurnal Ekonomi Pembangunan Universitas Udayana, 3(10).

Utdwinata, T., \& Murtini, S. (2019). Kajian Eksistensi Pedagang Kaki Lima Di Dupak Magersari Kelurahan Jepara 
Dinamika Sosial Budaya, Vol 22, No. 2, Desember 2020, pp 294-305

p-ISSN: 1410-9859\& e-ISSN: 2580-8524

http://journals.usm.ac.id/index.php/jdsb

Kecamatan Bubutan Kota Surabaya.

Swara Bhumi, 1(2).

Widjajanti, R. (2009). Karakteristik Aktivitas

Pedagang Kaki Lima Pada Kawasan

Komersial Di Pusat Kota Studi Kasus:

Simpang Lima Semarang. Teknik, 30(3).

Widjajanti, R. (2012). Karakteristik Aktivitas

Pedagang Kaki Lima di Ruang Kota

(Studi Kasus: Kawasan Pendidikan

Tembalang, Kota Semarang). Jurnal

Pembangunan Wilayah \& Kota, 8(4), 412-424.

Widyaningrum, N. (2009). Kota Dan

Pedagang Kaki Lima. Jurnal Analisis Sosial, 1(18).

Winoto, A., \& Budiani, S. R. (2017). KAJIAN KARAKTERISTIK DAN FAKTOR PEMILIHAN LOKASI PEDAGANG KAKI LIMA DI KOTA YOGYAKARTA. Jurnal Bumi Indonesia, 6(1).

Zulkarnain. (2012). Ilmu Menjual: Pendekatan Teoritis Dan Kecekapan Menjual. Yogyakarta: Graha Ilmu. 